\title{
제1차 한-UNDP 정책협의회 개최 결과
}

2006.8.21(월)-22(화)간 제1차 한-UNDP 정책 협의회가 국제연합대표부에서 개최되어 공동사업 선정 및 양측간 협력방안에 대해 논의하였는 바, 주요 결과 아래 보고함.

$$
\text { - 아 래 - }
$$

\section{1. 핵심 내용}

- 지난 4월 체결된 한-UNDP Partnership Framework Agreement”에 따라 1차로 내년 1 월부터 실시될 총 600 만불 규모의 4개(아프리 카 2개, 아시아 2개) 개도국원조 공동협력사업 을 선정하고 그 중 3 개 사업에 대한 Costsharing Arrangement에 서명함.

- 금번 협의시 새로운 제안 내용이 포함된 아 프리카 지역대상 1 개 사업에 대해서는 추후 사업 계획서 접수할 예정

- 우리측이 제기한 2008년도 집행이사국 진출
관련, $\mathrm{UNDP}$ 측은 호의적인 입장을 표명하며 우리나라의 집행이사국 진출을 지원하겠다고 하였는 바, 양측은 우리나라의 2008년도 집행 이사국 진출과 함께 현재 개도국 평균에 미치 지 못하는 수준(연간 1 백만불)의 자발적 기여금 을 증액하는 문제를 진지하게 검토할 필요가 있다는데 인식을 같이 함.

- 아울러 박석범 국제경제국장(현 KOICA 이 사)은 UNDP 서울사무소의 성격을 현재의 개도국 주재사무소에서 공여국(선진국) 주재 연락사무소로 성격을 바꾸는(re-profiling) 문제에 대해서도 $\mathrm{UNDP}$ 측에 검토를 요청하 였는 바, 이에 대해 $\mathrm{UNDP}$ 측은 필요성을 공 감하며 구체적인 협의를 추진키로 함.

- 우리측의 ODA정책수립 및 집행 - 평가능력 제 고를 위한 사업추진에 관하여 UNDP는 전적으 로 동의한다고 하면서 그 방안의 하나로 한국 측이 UNDP 사무국에 직원 1 명을 파견하는 것 을 제안하였음. 
- 상기 관련 Gilbert Houngbo UNDP 사무차 장보 겸 아프리카국장은 빈곤감축 및 $\mathrm{MDG}$ 달성과 관련하여 아프리카 개발정책수립지 원, 아프리카 이니셔티브 사업지원을 위해 우리측 파견관이 UNDP 아프리카국에 근무 토록 할 것을 제안함.

\section{2. 주요 논의 사항}

\section{가. 공동사업 선정}

- UNDP측이 제시한 사업중 우리측은 아프리카 및 아시아간 지역적 균형을 고려하여 각각 2개 사업을 2007년 1월부터 시작할 공동협력사업 으로 선정하였음.

- 아프리카 사업(2개) : "Institutional

Capacity Development for Regional Integration and Trade Policy Formulation and Negotiation" 및 반부패 관련 사업(추후 사업 계획서 접수 예정)

- 아시아 사업(2개) : "Building AntiCorruption Capacities for Implementing the MDGs" 및 "institutionalization of the MDGs Monitoring System in Mongolia Project"

- 상기 선정된 사업중 아프리카 지역 반부패 관 련 사업을 제외한 3 개 사업에 대한 Costsharing Arrangement에 서명함.

- UNDP측은 상기 3 개 사업에 대해 UNDP측 의 재정적 기여 확대를 요청한 우리측 수정
제안을 모두 수용함(3개 사업에 대해 UNDP 측이 총 110 만불을 추가 부담하고, KOICA 의 구체적 사업 참여를 확대하는 내용 포함).

- 상기 선정된 사업 외에 사업 내용이 충실하고 긍정적 사업효과가 기대되는 캄보디아 빈곤감 소 관련 사업은 차기 공동협력사업에 포함시 켜 추진키로 합의함.

- 아울러 우리 정부의 ODA 효율성 증대를 위한 $\mathrm{UNDP}$ 의 사업 제안 관련, 우리측은 우리 정부 의 $\mathrm{ODA}$ 효율성 제고를 위해 $\mathrm{OECD} / \mathrm{DAC}$ 에 비 공식적 절차인 light peer review를 신청할 계 획임을 언급하며 advocacy에 초점을 맞추어 동 사업을 추진하는 방안을 염두에 두면서 지 속 협의해 나가자고 함.

\section{나. 집행이사국(Executive Board) 진출}

- 우리측은 2000년말 UNDP 수원국(개도국)의 지위를 졸업한 이후 진출하지 못한 집행이사 국에 공여국(선진국)의 입장으로 진출하고자 하는 의사를 표명하면서 공여국 전환시 한국 $\mathrm{UNDP}$ 사무소의 성격 전환 등에 $\mathrm{UNDP}$ 측이 관심을 가져 줄 것을 요청함.

- 이에 대해 UNDP Bruce Jenks 사무차장보 겸 재원 및 전략적 파트너쉽 국장은 우리의 집행이사국 진출에 적극 협조하겠다고 하 면서 아울러 주한 UNDP 사무소를 공여국 연락사무소로 reprofiling하는 문제도 진지 하게 검토할 시점이 되었다고 생각한다고 언급함. 
- 아울러 동 국장은 우리 정부가 집행이사국 진출을 위해 우리의 지역적 소속을 수원국 위주의 아시아 지역에서 미국, 일본, 호주, 불란서, 영국 등으로 공여국으로 구성된 서 유럽 및 기타국가군(Western Europe and Other States)으로 전환하기 위해서는 아시 아지역 집행이사국들과 함께 서유럽 및 기 타국가군에 소속된 집행이사국 그룹과 모두 협의를 해야 할 것이라고 함.

※ 공여국 그룹 국가의 최소 연간 자발적 기 여금은 490만불 수준이며, 평균적으로 연간 약 1,000 만불 이상의 자발적 기여금 을 UNDP에 공여하는 것으로 파악됨.

\section{다. 양측 업무 소개}

- UNDP측은 UNDP의 개발정책 및 개도국 개 발지원사업, $\mathrm{MDG}$ 달성전략 등 업무 전반(아시 아 - 아프리카국 업무 소개 포함)에 대한 상세 한 설명과 함께 Result-based Management, 재무관리·기금회계 및 보고 절차 등 UNDP 재정관리 시스템에 대해 소개함(관련 자료 대 표단 지참 귀국 예정).

- 우리측은 국제경제국장이 최근의 ODA정책방 향, 항공권 연대기금, 아프리카이니셔티브 등 에 관해 전반적인 설명을 한 후, 정진규 경제기 구과장과 장현식 $\mathrm{KOICA}$ 정책연구실장이 각각 $\mathrm{ODA}$ 규모확대, ODA집행체제 효율화 방안, 심사평가능력제고 추진현황 및 상세한 KOICA 사업 활동에 대해 프레젠테이션함.

\section{Ocampo 사무차장 면담}

- 동 정책협의회 후, 우리측 수석대표는 Ocampo $\mathrm{UNDESA}$ 사무차장을 예방하고 금번 한$\mathrm{UNDP}$ 간 정책협의회 결과에 대해 설명하면서 동인의 협조를 요청하였으며, 동 사무차장은 우 리나라에 설립 예정인 UN 가버넌스 센터와 관 련하여 한국을 9 월 중 방문할 예정임을 언급하 면서 한국의 개도국 지원 노력과 국제개발원조 분야에 대한 적극적인 참여에 사의를 표명함.

\section{4. 관찰 및 평가}

- 양측은 금번에 처음으로 한-UNDP 정책협의 회' 가 개최된 것에 큰 의의를 부여하면서 금번 마련된 협력 모멘텀을 살려 내년초부터 추진될 공동사업 집행 - 평가 등 구체적 사업점검 및 개발원조지원 능력제고를 위한 정책협의를 매 년 정기적으로 개최하기로 결정하였는 바, 내 년도 정책협의회는 1 차년도 사업진행에 대한 중간보고 및 구체사업에 대한 공동평가에 초점 을 맞추어 개최될 것으로 전망됨.

- 공동협력사업 선정 이후에는 우리 정부의 $\mathrm{ODA}$ 집행기관인 $\mathrm{KOICA}$ 가 $\mathrm{UNDP}$ 와의 협의를 통해 사업의 세부 디자인에 참여하는 동시에 구체적 사업에 집행기관으로 참여하는 것이 바 람직할 것으로 판단되는 바, KOICA가 구체적 인 사업참여방안을 수립하여 본부와 협의해 줄 것을 건의함. 
- UNDP측은 국제개발원조기구에서 공여국의 지위로 국제원조정책 수립에 참여하고 있는 국 가들은 현재 모두 $\mathrm{OECD} / \mathrm{DAC}$ 회원국들인 바, 국제무대에서 진정한 의미의 공여국으로서 지 위를 인정받기 위해서는 UNDP 집행이사국 진 출과 병행하여 $\mathrm{OECD} / \mathrm{DAC}$ 가입을 추진하는 것이 필수적이라고 지적함.
- 동 지적과 관련 향후 UNDP 집행이사국 진 출추진과 더불어 $\mathrm{OECD/DAC가입} \mathrm{일정을}$ 조속 확정하여 추진할 필요가 있음.

[자료: 주국제연합대표부] 